\title{
ANTIBACTERIAL ACTIVITY OF SOME MEDICINAL PLANTS OF SRI LANKA
}

\author{
C.M. HEWAGE ${ }^{1}$, B.M.R. BANDARA ${ }^{1}$, V. KARU̇NARATNE ${ }^{1 *}$, G.P. WANNIGAMA ${ }^{1}$, \\ M.R.M. PINTO ${ }^{2}$ and D.S.A. WIJESUNDARA ${ }^{3}$ \\ ${ }^{1}$ Department of Chemistry, University of Peradeniya, Peradeniya. \\ ${ }^{2}$ Department of Microbiology, University of Peradeniya, Peradeniya. \\ ${ }^{3}$ Royal Botanic Gardens, Peradeniya.
}

(Received: 08 August 1997; accepted: 06 February 1998)

\begin{abstract}
Plant extracts from 55 plants were screened for antibacterial activity against Staphylococcus aureus, Escherichia coli, and Mycobacterium. fortuitum. Hortonia angustifolia (root) showed very high activity against Mycobacterium fortuitum ; Artemisia dubia (leaf), Celtis cinnamomea (stem), Curcuma longa (tuber), Lobelia aromatica (leaf), Ocimum gratissimum (aerial part), Pimenta officinalis (stem bark), Thespesia populnea (stem), Ulex europaeus (whole plant) showed significant activity against at least one of the above organisms.
\end{abstract}

Key words: Antibacterial activity, medicinal plants.

\section{INTRODUCTION}

The search for new antibiotics with hitherto unknown modes of action remains an urgent priority as microbial resistance to antimicrobial agents continues to unfold as one of the most difficult problems facing the physicians dealing with infectious diseases. There is virtually no drug that is free of this problem, as genes for resistance have emerged and spread at an alarming rate. ${ }^{1.2}$ So far the majority of clinically used antibiotics are obtained from microorganisms, lower plants such as fungi and algae, symbiotic lichens and mosses. ${ }^{3}$ On the other hand, higher plants contain a reservoir of antibiotics which have so far remained underutilized. ${ }^{3}$ Many plants which are resistant to microorganisms have been shown to produce antibiotics. ${ }^{3}$

The flora of Sri Lanka comprise about 3,300 flowering plants of which about $830(25 \%)$ species are endemic to the island. ${ }^{4}$ The variations in soil conditions, temperature and humidity are reflected in a wide range of flora. Most of the plant species found in Sri Lanka are the same as those found in the Indian subcontinent. However, the high percentage of endemic plants in the island, compared to most countries in the region, makes it a fertile testing ground for the phytochemist. Attygalle ${ }^{5}$ has described a large number of plants of medicinal value in his compilation of 'Sinhalese Materia Medica'. The pioneering work by Chandrasena ${ }^{6}$ in 1935, has listed the earliest chemical studies and the pharmacological activity of Sri Lankan and Indian plants.

The present study describes the investigation of 101 plant extracts derived from 55 medicinal plants of Sri Lanka, for antibacterial activity against Staphylococcus aureus, Escherichia coli and Mycobacterium fortuitum. 
$S$. aureus and $E$. coli were chosen because standard strains of these organisms are sensitive to almost all commonly used antibiotics. S. aureus is found in $10-20 \%$ of normal healthy adults and is one of the commonest pathogens in skin wounds. ${ }^{7} M$. fortuitum, is an acid fast soil bacterium and was selected as representative of the genus Mycobacterium for the following reasons: ${ }^{8}$ It is a rapidly growing bacterium (results could be evaluated in 7-14 days) and grows in simple media with little enrichment. Furthermore, $M$. fortuitum is easier to handle being ordinarily non-pathogenic; it rarely causes pulmonary disease but usually causes wound infections, post infection abscesses, and contamination of the porcine valve used for heart valve replacement of humans. However, $M$. fortuitum shows full resistance to most antitubercular drugs. ${ }^{8}$

\section{METHODS AND MATERIALS}

\section{Plant material}

Plant material used in this study were mature (reproductive maturity) specimens (1-5 kg) collected from different localities of Sri Lanka, mostly from the Central Province of Sri Lanka. All plants collected were true species. ${ }^{9.4}$ Plant specimens were identified by comparison at the National Herbarium, Royal Botanic Gardens, Peradeniya. ${ }^{9,4}$ The specimens were immediately washed with running water to remove contaminated soil and other surface impurities. They were cut into small pieces about $3-6 \mathrm{~cm}$ in length. The specimens were immediately shade-dried and powdered in a laboratory mill.

\section{Preparation of plant extracts}

The air-dried and ground plant material $(100 \mathrm{~g})$ were extracted into $500 \mathrm{ml}$ of hot methonol or successively with $500 \mathrm{ml}$ each of hot hexane/light petroleum $\left(40-60^{\circ} \mathrm{C}\right)$, dichloromethane, ethyl acetate, in a Soxhlet apparatus. Some were extracted directly with cold ethyl acetate and cold methanol in a bottle shaker. The solubles were concentrated to dryness separately using a rotavapor (below $45^{\circ} \mathrm{C}$ ). The extracts were subjected to antibacterial assay as described below.

\section{Antibacterial screening}

Tests for antibacterial activity ${ }^{10}$ were carried out using type strains of S. aureus (NCTC 6571), E.coli (NCTC 10418) and M. fortuitum \{3010/82 (4974) Brisbane\}. The plant extracts (16 mg each) were weighed and dissolved in $4 \mathrm{ml}$ of absolute alcohol in test tubes. From this solution $0.4 \mathrm{ml}$ was transferred to a sterile nutrient broth solution ( $10 \mathrm{~g}$ peptone, $10 \mathrm{~g}$ beef extract and $5 \mathrm{~g} \mathrm{NaCl}$ in $1000 \mathrm{ml}$ of distilled water; the medium was autoclaved at $15 \mathrm{lb}$ pressure for $15 \mathrm{~min}$ ) to prepare tenfold dilutions. A series of doubling dilutions were then dispensed in $2 \mathrm{ml}$ aliquots, in test tubes, with concentrations ranging from 1/10 to $1 / 5120$ and inoculated with a fixed bacterial inoculum $\left(0.1 \mathrm{ml}\right.$ of a $10^{-4}$ dilution of bacterial suspension with a density of a $2 \%$ aqueous suspension of barium sulphate). Different bacterial cultures were inoculated separately. Simultaneously, the 
bacterial inoculum was also made into an identical set of tubes of dilutions made from ethanol alone, and a tube each of nutrient broth, these being used as controls. The tubes were incubated at $37^{\circ} \mathrm{C}$ for $24 \mathrm{~h}$ except for $M$. fortuitum which was incubated for 7 days. The tubes were examined for turbidity with the naked eye. The minimal inhibitory concentration (MIC), which is the lowest concentration which prevents the development of turbidity of the extracts was determinined. To confirm the naked eye reading, a loopful of mixture from each of these tubes were then inoculated on nutrient agar and incubated as before. The subculture from the tube containing the MIC formed no more than a few colonies and the subcultures from the tubes containing bactericidal concentration formed no growth at all. The minimal bactericidal concentration (MBC) was considered to be that showing no growth or less than 20 colonies on a semisolid medium. In the interpretation of results, the test solutions were compared with those of alcohol dilutions. All experiments were carried out under steri].e conditions.

\section{RESULTS AND DISCUSSION}

Most of the plants used in the study are used in ethnomedical preparations in Sri Lanka. "Some plants have been selected on the basis that they are widely distributed and apparently free of pest/microbial attack. Some plants were chosen due to the presence of compounds that are useful and/or having interesting biological properties. For example Curcuma longa and Artemisia dubia are used ethnomedically. C. longa is used as both a colouring material and condiment. ${ }^{11}$ This plant contains curcumin, ${ }^{12}$ juvabione, ${ }^{13}$ and some sesquiterpenoids. ${ }^{14}$

Of the plants which are promising, most showed antibacterial activity against one organism only (Table 1). The hot methanol extract of Hortonia angustifolia (Rt) showed highest activity against $M$. fortuitum. Interestingly, the hot methanol extract of $H$. angustifolia has shown strong antifungal activity (against Cladosporium cladosporioides) ${ }^{15}$ while both its Rt and Lf has shown significant insecticidal activity against Aphis craccivora. ${ }^{16,17}$ The cold methanol extract of Artemisia dubia (Lf), hot methanol extract of Celtis cinnamomea (St), cold ethanol and methanol extracts of Curcuma longa ( $\mathrm{Tb})$, and hot methanol extracts of Lobelia aromatica (Lf), Ocimum gratissimum (Ap), Pimenta officinalis (St Bk), Thespesia populnea (St) and Ulex europaeus (Wp) showed significant activity. The hot methanol extracts of Cestrum aurantiacum (Lf and St), Chrysopogon zeylanicus (Wp), Eupatorium odoratum (Lf), Gaultheria rudis (Wp-Lf), Glochidion montanum (Lf), Hortonia angustifolia (St), Hypericum mysurense (St), Leucas zeylanica (Wp), Lobelia nicotianifolia (Lf), Phyllanthus embilica (Lf), Phyllanthus reticulatus (Lf) and Psychotria nigra (Lf) showed only moderate activity. 
Table 1: Antibacterial activity of some medicinal plants of Sri Lanka against Staphylococcus aureus, Escherichia coli and Mycobacterium fortuitum.

\begin{tabular}{|c|c|c|c|c|}
\hline $\begin{array}{l}\text { Plant (Family) }{ }^{\sharp} \\
{[\text { Sinhala/Tamil] }}\end{array}$ & Collection & Part: & Solvent' & $\begin{array}{l}\text { Minimal } \\
\text { Bactericidal } \\
\text { Concentration } \\
\text { (MBC) } \mu g / \mathrm{ml}^{\mathrm{c}} \\
\text { Stap. Myco E. coli }\end{array}$ \\
\hline
\end{tabular}

+ Actinodaphne speciosa Nees.

(Lauraceae) [S-Alikan]

Allaeophania decipiens Thw.

(Rubiaceae)

Alpinia abundiflora

Burtt \& Smith

(Zingiberaceae)

+Alpinia fax Burtt \& Smith

(Zingiberaceae)

Alpinia nigra (Gaertn.) Burtt

(Zingiberaceae) [S-Alugas,

T-Shitai rattai]

Anotis richardiana (Arn.) Hook.

(Rubiaceae)

Artemisia dubia var. grata Wall

(Compositae) [S-Walkolondu,

T-Marukolondu]

Bridelia retusa (L.) Spreng

(Euphorbiaceae) [S-Ketakela,

T-Adamarudu]

Butea monosperma (Lam.) Taub.

(Leguminosae) [S-Gaskela,

T-Parasu]

Celtis cinnamomea Lindl. ex

Planch. (Ulmaceae) [S-Gurenda,

T-Pinari]

Cestrum aurantiacum Lindl.

(Solanaceae)

Chrysopogon zeylanicus

(Steud.) Thw.

(Gramaceae) [S-Gawara]

Costus speciosus (Koen.) Sm.

(Zingiberaceae)

[S-Tebu, T-Khoshadam]

Curcuma longa L.

(Zingiberaceae)

[S-Kaha, T-Manchal]

Curcuma zedoaria

(Berg.) Roscoe.

(Zingiberaceae) [S-Harankaha,

T-Kasturimangal\}

Eupatorium inulifolium $\mathrm{HBK}$.

(Compositae)

Eupatorium odoratum L.

(Compositae)

[S-Podisinghomaran]

\begin{tabular}{|c|c|c|}
\hline Horton Plains & Lf & $\mathrm{MeOH}^{\mathrm{h}}$ \\
\hline \multirow[t]{2}{*}{ Horton Plains } & Ap & $\mathrm{MeOH}^{\mathrm{h}}$ \\
\hline & St & $\mathrm{MeOH}$ \\
\hline \multirow[t]{2}{*}{ Horton Plains } & $\mathrm{Rh}$ & Pet \\
\hline & & $\begin{array}{l}\mathrm{CH}_{2} \mathrm{Cl}_{2}{ }^{11} \\
* \mathrm{MeOH}{ }^{\prime \prime}\end{array}$ \\
\hline Rakwana & $\mathrm{Tb}$ & MeOH" \\
\hline \multirow[t]{2}{*}{ Hakgala } & Ft & $\mathrm{MeOH}$ \\
\hline & $\mathrm{Tb}$ & $\mathrm{MeOH} \mathrm{H}^{\mathrm{h}}$ \\
\hline Pattipola & $\mathrm{Wp}$ & $\mathrm{MeOHI}^{\prime \prime}$ \\
\hline \multirow[t]{6}{*}{ Ambawela } & $\mathrm{Lf}$ & $\mathrm{MeOH}^{\mathrm{c}}$ \\
\hline & Lf & MeOH' \\
\hline & St & $\mathrm{MeOH}$ \\
\hline & St & $\mathrm{MeOH}^{\prime \prime}$ \\
\hline & Rt & $\mathrm{MeOH}^{\mathrm{c}}$ \\
\hline & $R t$ & $\mathrm{MeOH}^{\mathrm{l}}$ \\
\hline Kandy & Lf & $\mathrm{MeOH}$ \\
\hline
\end{tabular}

Mahiyangana St Bk EtOH

$\begin{array}{llllll}\text { Hakgala } & \text { Lf } & \mathrm{MeOH}^{\prime \prime} & - & - & - \\ & & & & \\ \text { Hakgala } & \text { St } & \mathrm{MeOH}^{\prime \prime} & 25 & - & 50 \\ & \text { Lf } & \mathrm{MeOH}^{\prime \prime} & 50 & - & - \\ \text { Hakgala } & \text { St } & \mathrm{MeOH}^{11} & - & - & - \\ \text { Wp } & \mathrm{MeOH}^{\prime \prime} & 100 & - & 50\end{array}$

Kalutara $\quad \mathrm{Rh} \quad \mathrm{MeOH}$

Kandy

$\mathrm{Tb} \quad \mathrm{EtOH}$

Tb. $\mathrm{MeOHc}$

25

Kandy

Tb MeOE'

Hakgala

St $\mathrm{MeOH}$

StBk MeOH"

Kandy
50 
Table 1 Contd.

\begin{tabular}{|c|c|c|c|c|}
\hline $\begin{array}{l}\text { Plant (Family) } \\
\text { [Sinhala/Tamil] }\end{array}$ & Collection & Part ${ }^{\mathrm{a}}$ & Solvent & $\begin{array}{l}\text { Minimal } \\
\text { Bactericidal } \\
\text { Concentration } \\
\text { (MBC) } \mu g / \mathrm{ml}^{\circ} \\
\text { Stap. Myco E. coli }\end{array}$ \\
\hline
\end{tabular}

Eupatorium riparium Regel.

(Compositae)

Gaultheria rudis Stapf.

(Ericaceae) [S-Wal kapuru]

Glochidion montanum Thw.

(Euphorbiaceae)

Gynostemma laxum. (Wall.) Cong.

(Cucurbitaceae)

+ Hortonia angustifolia

(Thw.) Trim.

(Monimiaceae)

+Hortonia floribunda

Wight ex Arn.

(Monimiaceae) [S-Gawara]

Hypericum mysurense

Wight \& Arn.

(Gutiferae)

Justicia betonia L.

(Acanthaceae) [S-Sudu puruk]

Leucas biflorc (Vahl.) Benth.

(Labiatae) [S-Geta tumba,

T-Peyt tumpi\}

Leucas zeylanica (L.) Benth.

(Labiatae) [S-Geta tumba,

T-Mudi tumpi]

Lobelia aromatica Moon ex Wight

(Lobeliaceae)

Lobelia nicotianifolia

Roth ex R. \& Schult

(Lobeliaceae) [S-Waldunkola,

T-Kattupoillai]

+ Mastixia tetrandra

(Wight ex Thwaites) C. B. Clarke

(Cornaceae) [S-Matawara]

Ocimum gratissimum L.

(Labiatae) IS-Gastala,

T'-Elumichantulasi]

Osbeckia cupularis D. Don ex

Wight \& Arn.

(Melastomaceae) [S-Bowitia]

Pedalium murex L.

(Pedaliaceae) [S-Ethnerenchi,

T-Perunerenchi]

Phyllanthus embilica L.

(Euphorbiaceae) [S-Nelli,

T-Nelli]

Phyllanthus reticulatus Poir.

(Euphorbiaceae) [S-Welkayila, T-Pulla]

Pimenta officinalis Lindl.

(Myrtaceae)
Hakgala

Rt

Horton Plains

Hakgala

Hakgala

Sinharaja

Hakgala

Pattipola

Kandy

Horton Plains

Hakgala

Wp MeOH'

100

Horton Plains

$\begin{array}{ll}\text { Lf } & \mathrm{MeOH}{ }^{\prime \prime} \\ \text { St Bk } & \mathrm{MeOH}{ }^{\prime \prime} \\ \text { Lf } & \mathrm{MeOH} \\ \text { St Bk } & \mathrm{MeOH}^{\prime \prime}\end{array}$

Hakgala

Lf $\mathrm{MeOH}$
Kandy

Ap $\mathrm{MeOH}^{\prime \prime}$

Rt $\mathrm{MeOH}^{\mathrm{n}}$

Horton Plains Wp $\mathrm{MeOH}^{\mathrm{h}}$

Puttalam

Lf $\quad \mathrm{MeOH}^{\mathrm{n}}$

Hakgala

Lf $\mathrm{MeOH}^{\mathrm{h}}$

50

Sigiriya

Lf $\mathrm{MeOH}^{\mathrm{h}}$

100

25

Kandy Lf $\mathrm{MeOH}^{\mathrm{t}}$

$\mathrm{St} \mathrm{Bk} \mathrm{MeOH}^{\prime \prime}$ 
Table 1 Contd.

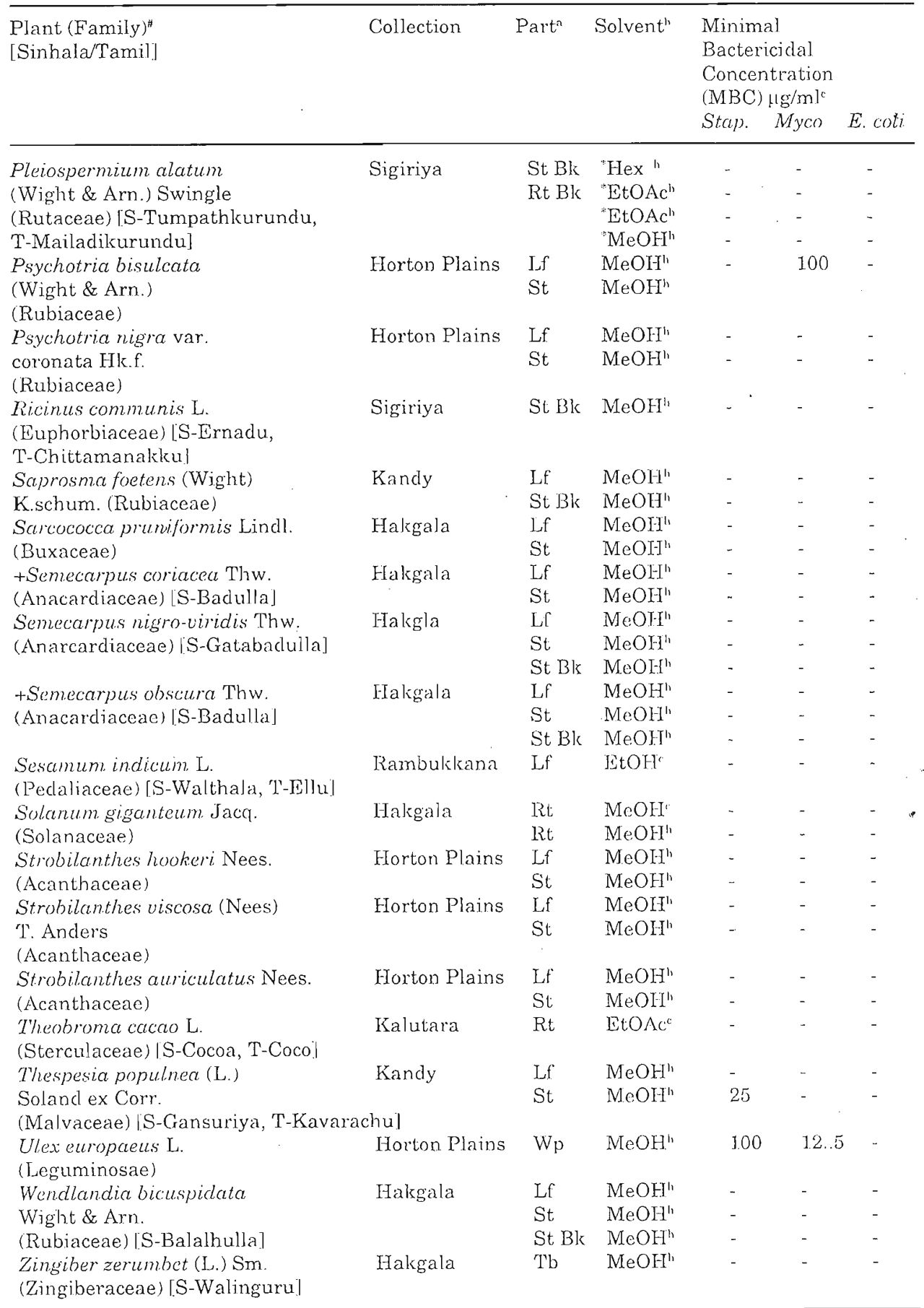

\# : Nomenclature follows W.M. Bandaranayake et al. ${ }^{4},+$ : Species endemic to Sri Lanka *: Successive extraction, a : Ap - aerial part; Lf - leaf, Rh - rhizome; Rt - root; St Bk - stem bark; Tb-tuber; Wp-whole plant, b : h - hot extracion; Hex - n-hexane, c: (-) - no activity. 


\section{Acknowledgement}

The authors are grateful to NARESA, Sri Lanka and IFS Sweden for financial support.

\section{References}

1. Antibiotic resistance genes: ecology, transfer and expression. Banbury Report No. 24, Cold Spring Habour Laboratory, (Eds. S.B. Levy. \& R.P. Novick) (1986) p 3.

2. Antimicrobial therapy (Eds. A.M. Ristuccia \& B.A. Cunha) (1984). Raven Press, New York, 11-21.

3. Medical botany-plants affecting man's health, (Eds. E.D. Lewis \& M.P.F. Elvin-Lewis) (1977), pp. 355-371.

4. Bandaranayake W.M., Sultanbawa M.U.S., Weerasekara S.C. \& Balasubramaniam S.(1974). Sri Lanka Forester 11(3-4), 67.

5. Attygalle J.(1917). Sinhalese Materia Medica, M.D. Gunesena \& Co. Ltd., Colombo, Ceylon.

6. Chandrasena J.P.C. (1935). The chemistry and pharmacology of Ceylon and Indian medicinal plants, $\mathrm{H} \& \mathrm{C}$ Press, Colombo, Ceylon.

7. Stokes J. (1968). Clinical bacteriology. Edward Arnold Publishers Ltd., London.

8. Manual of clinical microbiology. American Society for Microbiology 4 th ed. (Ed. E.H. Lennette) (1985), p 240.

9. Dassanayake M.D. \& Fosberg F.R.(1983). A revised handbook to the flora of Ceylon, Amarind Publishers, New Delhi, Vol. I-VIII.

10. Cruickshank R. (1965). A Guide to laboratory diagnosis and control of infection. In: Medical Microbiology. pp. 190-208. E. \& S. Livingston Ltd., Edinburgh .

11. Medicinal and Aromatic Plants Abstracts CSIR, New Delhi, India, 1986. 8(4): 386.

12. Janaki N. \& Bose J.L. (1967). Journal of the Indian Chem. Soc. 44(11): 98586.

13. Ayyar K.S. \& Rao G.S.K. (1967). Tetrahedron Lett. 47: 4677-82. 
14. Kiso, Y., Suzuki, Y., Oshima, Y.\& Hikino, H. (1983). Phytochemistry 22(2): 596-7.

15. Bandara B.M.R., Fernando I.H.S., Hewage C.M., Karunaratne V., Adikaram N.K.B. \& Wijesundara D.S.A. (1989). Journal of the National Science Council of Sri Lanka 17 (1): 1-13.

16. Hewage C.M. (1990). M.Sc. Thesis. University of Peradeniya.

17. Hewage C.M., Bandara K.N.A.P., Karunaratne V., Bandara B.M.R. \& Wijesundara D.S.A.(1997). Journal of the National Science Council of Sri Lanka 25(3): 141-150. 